\title{
URGENSI HUKUMAN BERAT BAGI PELAKU TINDAK PIDANA KORUPSI
}

Petrus Irwan Pandjaitan ${ }^{*}$

\begin{abstract}
Financial Loss of State is the basis to declare the existence of Corruption Crime Action, and the basis to punish the doers is UURI No 31 year 1999 subject Fighting of Corruption to classify the forms of the punishment, such as : dead sentence, inprison, fines, substation money and take over of aset, in criminal law it is confessed a logic which states that dangerous nature and damage of an action become the reason to criminalize an action as a criminal action, and have to have falses, because just only by having falses a person can be punished, but it has to have coorelation between the action that cause loss with the punishment given, in the form of the state financial in certain amount, corruption as an extra ordinary crime, conducted by many official Officers and the country executors, besides, corruption has damage Behavior and mental of the executors which are accustomed to live with luxiouristy, the corrutption itself has cause loss for public and the doers shall be given fair punishment that is the punishment as heavy as possible or dead sentence if necessary, to punish the doers of corruption, shall have certain purpose, such as to save state property, to stop the doers of doing such things, and to prevent other people not to conbduct corruption, by that way it is necessary to punish the doers of corruption with heavy punishment simply not only to stop of doing corruption but it is understood as a form of justice and recovery of social relation between the Doer and the state and the public, so that later on after the doer has completed its punishment it will not rejected by the public.
\end{abstract}

Kata Kunci : Hukuman berat

\section{Pendahuluan}

Korupsi sebagai perbuatan menyimpang menjadi perhatian serius dari Pemerintah dan Masyarakat, Sehingga harus dicegah dan ditanggulangi dengan cara-cara yang sangat luar biasa. Salah satu perhatian masyarakat dari Tindak Pidana Korupsi adalah Perlakuan terhadap Pelaku. Dalam hal Ini masyarakat menghendaki agar Hakim menjatuhkan hukuman yang layak bagi pelaku, yaitu : hukuman seberat-beratnya. Tuntutan dan kehendak masyarakat demikian, menjadi tantangan bagi Pemerintah terlebih Institusi Penegak Hukum. Dalam hal ini, Penegak Hukum harus berani mengungkap perkara korupsi, yang dilakukan Pejabat dan Penyelenggara Negara atau siapa saja, serta harus diadili. Tujuannya menyelamatkan uang negara, menjerakan pelaku dan mencegah orang lain melakukan korupsi.

Sebagai kejahatan luar biasa, korupsi menjadi perbincangan setiap orang hampir di semua tempat. Dalam hal ini, Korupsi diyakini sebagai "penyakit" yang menderitakan dan harus dibasmi walaupun sulit dan rumit. Mem- basmi Korupsi dapat dilakukan dengan cara memperketat pengawasan, membuat aturanaturan yang jelas dan tidak menimbulkan keraguan bagi Pengguna Anggaran, serta tidak menimbulkan multi tafsir bagi Penegak hukum. Disamping itu, harus ada supervisi dan koordinasi antara : Instansi Pemerintah dengan Badan Pemeriksa Keuangan Negara, serta Komisi Pemberantasan Korupsi mengenai penggunaan uang negara.

Korupsi sebagai suatu konsep hukum, dirumuskan sebagai suatu Perbuatan yang mengakibatkan kerugian keuangan Negara, memperkaya diri sendiri, orang lain, maupun korporasi. Korupsi pada umumnya dilakukan oleh Pegawai Negeri, Pejabat serta Penyelenggara Negara atau orang-orang yang memperoleh upah dari uang Negara. Dampak dari Korupsi adalah : masyarakat menjadi "miskin", Negara dapat menjadi "bangkrut", serta hilangnya kepercayaan Masyarakat terhadap Pemerintah. Akibat korupsi dirasakan langsung oleh masyarakat, seperti: terbatasnya lapangan pekerjaan, minimnya fasilitas Pendidikan dan

${ }^{*}$ Dosen Tetap Fakultas Hukum UKI Jakarta 
kesehatan. Semua itu menimbulkan kebencian dan kemarahan, sehingga ada tuntutan agar Pelaku dihukum seberat-beratnya, dibuat "miskin" dan di Hukum Mati. Sejalan dengan itu, Menghukum pelaku Tindak Pidana Korupsi, tentu harus berdasarkan undang-undang serta melalui putusan hukum oleh hakim di Pengadilan. Adapun hukuman yang dapat dijatuhkan Hakim berupa : Pidana Penjara, Pidana mati, Perampasan aset, Uang Pengganti, Pidana denda.

\section{Permasalahan}

Permasalahan didalam tulisan ini, adalah : (1). Apakah Hukuman Berat itu harus setimpal dengan kerugian keuangan Negara ; serta (2). Apakah hukuman berat itu dapat menjerakan; (3). Apa Urgensi dari beratnya Hukuman bagi Pelaku Tindak Pidana Korupsi.

\section{Tujuan Penulisan}

Sejalan dengan itu, Tulisan ini bertujuan untuk mengetahui : (1). bahwa Hukuman itu harus setimpal dengan kerugian keuangan $\mathrm{Ne}-$ gara; serta (2). hukuman itu harus dapat mencegah dan menjerakan; (3). Hukuman harus dapat menyadarkan Pejabat dan Penyelenggara Negara untuk tidak korupsi, memulihkan hubungan Pelaku dengan Negara dan Masyarakat; mencegah agar Pelaku tidak ditolak Masyarakat.

\section{Kerugian Dan Hukuman}

Di dalam Logika Hukum Pidana, dipahami dasar untuk mengkriminalisasi suatu perbuatan, adalah sifat berbahaya dan merugikannya suatu perbuatan. Dalam Hal ini, menganiaya, membunuh dan mencuri, harus dilarang karena perbuatan itu berbahaya bagi fisik, nyawa, serta harta benda orang lain. Dengan demikian, bilamana perbuatan itu dilakukan, maka kepada pelaku diberi sanksi berupa hukuman. Menghukum seorang pelaku kejahatan dengan jenis hukuman tertentu, sepatutnya berkorelasi dengan perbuatan dan nilai kerugian yang ditimbulkan. Sejalan dengan itu : ${ }^{1}$ ajaran schuttznormtheorie atau ajaran relativitas, suatu ajaran yang melihat perlunya ada kaitan antara kewajiban mengganti kerugian

\footnotetext{
Indriyanto Seno Adji, Korupsi Kebijakan Aparatur Negara dan Hukum Pidana, Jakarta : Diadit Media, 2006, hal 45-46
}

dengan persyaratan perbuatan melawan hukum. seseorang yang melakukan perbuatan melawan hukum diwajibkan memberikan ganti rugi akibat perbuatannya, hanya apabila pelanggaran kaidah itu ditujukan bagi orangorang yang kepentingan hukumnya memang dilindungi oleh kaidah hukum itu.

Dengan demikian, kerugian itu menjadi dasar utama untuk menuntut ganti kerugian, bahkan menghukum atau menuntut balas atas perbuatan seseorang. Berkaitan dengan itu, Undang-undang RI No 31 tahun 1999 tentang Tindak Pidana Korupsi yang telah disempurnakan dengan UU RI No 20 tahun 2001, menyebutkan bahwa kerugian pada keuangan Negara menjadi unsur utama adanya tindak pidana korupsi dan sekaligus menjadi landasan untuk menghukum pelaku.

Berkaitan dengan kerugian keuangan Negara, ${ }^{2}$ Yunus Husein menyatakan terjadinya kerugian negara disebabkan: ${ }^{3}$ kerugian negara yang terkait dengan berbagai transaksi: transaksi barang dan jasa, transaksi yang terkait dengan utang-piutang, dan transaksi yang terkait dengan biaya dan pendapatan. lebih lanjut Yunus Husein menyatakan bahwa beberapa kemungkinan peristiwa yang

2 Kerugian dapat dihitung baik dari Hukum Perdata, Hukum Administrasi Negara, Kerugian Menurut UU RI No 31 tahun 1999 tentang Pemberantasan Tindak Pidana Korupsi. Didalam Hukum Perdata Yang dimaksud kerugian yang dapat dimintakan pergantian itu, tidak hanya berupa biaya-biaya yang sungguhsungguh telah dikeluarkan (kosten) atau kerugian yang sungguh-sungguh menimpa harta benda si berpiutang (schaden), tetapi juga yang berupa kehilangan keuntungan (interessen), yaitu keuntungan yang akan didapat seandainya si berutang tidak lalai (winstderving). Kerugian menurut Hukum Administrasi Negara, Undang-undang tentang Perbendaharaan Negara (UU RI No 1 tahun 2004)memberikan defenisi tentang "kerugian" dalam konteks kerugian Negara/daerah. pasal 1 ayat 22 undang-undang ini berbunyi : Kerugian Negara/daerah adalah kekurangan uang, surat berharga, dan barang, yang nyata dan pasti jumlahnya sebagai akibat perbuatan melawan hukum baik sengaja maupun lalai. Pengertian Kerugian menurut UU RI No 31 tahun 1999 tentang Pemberantasan Tindak Pidana Korupsi, dapat dilihat pada pasal 2 dan 3. (Theodorus M. Tuanakotta, Menghitung Kerugian Keuangan Negara dalam Tindak Pidana Korupsi, Jakarta : Salemba Empat, 2009, halaman 78-82).

3 Yunus Husein, Negara Sang Pencuci Uang, Jakarta : Pustaka Juanda Tiga Lima, 2008, hal 184. 
dapat merugikan keuangan negara. ${ }^{4}$ Bila melihat pendapat Yunus Husein tersebut, maka sangat besar nilai kerugian negara akibat korupsi yang dapat dinilai dengan uang, yang dinikmati oleh pelaku. Dalam Hal ini, wajar bila ada "derita" atau "yang tidak mengenakkan" diberi kepada pelaku melebihi kesenangan yang diperoleh atas kekayaan negara yang diperoleh ataupun dinikmati. Besar kecilnya nilai kerugian keuangan negara tentunya agak sulit mengukur dengan berapa lama seseorang pelaku itu harus menerima hukuman, yang pasti bahwa ada hukuman karena memang ada perilaku yang berbahaya dan merugikan.

Dalam pada itu juga, pembentuk undang-undang tidak selamanya menilai harus telah terjadi kerugian dalam bentuk materi atau uang, namun dasar penjatuhan hukuman, dilihat pada sifat atau niat jahat pelaku korupsi itu menjadi salah satu pertimbangan dalam memberi hukuman. Hal ini dapat kita lihat pada pengembalian kerugian keuangan Negara atau perekonomian Negara tidak menghapuskan pidana bagi pelaku sebagaimana dimaksud Undang-undang RI No 31 tahun 1999 pasal 2 dan pasal 3.** Dengan demikian adanya hukuman

4 Pertama, terdapat pengadaan barang dengan harga yang tidak wajar, karena jauh dari harga pasar, sehingga dapat merugikan keuangan negara sebesar selisih harga pembelian dengan harga pasar atau harga wajar. korupsi didalam proses pengadan barang jasa inilah yang paling banyak terjadi di Indonesia. kedua, Harga pengadaan barang dan jasa wajar. wajar tetapi tidak sesuai dengan spesifikasi barang dan jasa yang di isyaratkan. kalau harga barang dan jasa murah, tetapi kualitas barang dan jasa itu kurang baik, maka dapat dikatakan juga merugikan keuangan negara. ketiga, terdapat transaksi yang memperbesar utang negara secara tidak wajar, sehingga dapat dikatakan merugikan keuangan negara karena diwajibkan negara untuk membayar hutang semakin besar. Keempat, Piutang negara berkurang secara tidak wajar dapat juga dikatakan merugikan keuangan negara. kelima kerugian negara dapat terjadi kalau aset negara berkurang karena dijual dengan harga yang murah atau dihibahkan kepada pihak lain atau ditukar dengan pihak swasta atau perorangan (ruislag). ke enam, dengan memperbesar biaya instansi atau perusahaan. hal ini dapat terjadi baik karena pemborosan maupun dengan cara lain seperti membuat biaya fiktif. ketujuh, hasil penjualan suatu perusahaan dilaporkan lebih kecil dari penjualan sebenarnya, sehingga mengurangi penerimaan resmi perusahaan tersebut. Ibid Hal 184-185

** UU RI No 31 tahun 1999 tentang Pemberatasan Tindak Pidana Korupsi , pasal 2 dirumuskan : Pidana berat atau ringan ukurannya bukan terletak ada tidaknya kerugian keuangan Negara semata.

Sejalan dengan itu, menghukum seorang pelaku kejahatan adalah suatu pekerjaan yang sulit, apalagi bila ada sesuatu yang diharapkan. Mengingat berbagai aspek yang melingkupi pelaksanaan hukuman itu, seperti : menyediakan infrastruktur, anggaran biaya, sumber daya manusia yang harus memiliki kualifikasi tertentu, belum lagi perangkat dan pola pembinaan bagi terpidana. Sebagai suatu derita yang sengaja diberikan, hukuman memiliki sisi positif dan negatif, baik kepada pelaku maupun kepada masyarakat. Menghukum pelaku korupsi, memiliki makna bahwa Rasa keadilan masyarakat terpenuhi, dimana hukum sudah ditegakkan. Sedang sisi negatif nya adalah seseorang itu diasingkan dari lingkungan sosial serta keluarga begitupula keinginan serta kebebasannya dibatasi dan keluarga menanggung "malu" bahkan " diasingkan dari masyarakat".

Kemanfaatan suatu hukuman, kerapkali dipahami berbeda baik oleh penegak hukum maupun masyarakat. Menderitakan pelaku sepertinya menjadi hal utama bagi masyarakat ketimbang menjerakan. Masyarakat menginginkan agar pelaku korupsi yang telah menikmati uang hasil korupsi jangan sekali-kali diberi rasa aman, atau dilindungi bahkan diberi fasilitas apapun. Penilaian masyarakat tentang

Penjara paling singkat 4 (empat) tahun dan paling lama 20 (duapuluh) tahun dan denda paling sedikit Rp 200.000.000.- (dua ratus juta rupiah) dan paling banyak Rp 1.000.000.000 (satu milyar rupiah), serta dalam hal tindak pidan korupsi sebagaimana dimaksud dalam ayat (1) dilakukan dalam keadaan tertentu, pidana mati dapat dijatuhkan. Disamping Pidana Pokok, kepada terpidana juga diberi Pidana Tambahan sebagaimana bunyi pasal 18 yang memuat : (a). perampasan barang bergerak yang berwujud atau yang tidak berwujud atau barang tidak bergerak yang digunakan untuk atau yang diperoleh dari tindak pidana korupsi, termasuk perusahaan milik terpidana dimana tindak pidana korupsi dilakukan, begitupula harga dari barang yang menggantikan barang-barang tersebut; (b). Pembayaran uang pengganti yang jumlahnya sebanyak-banyaknya sama dengan harta benda yang diperoleh dari tindak pidana korupsi; (c). penutupan seluruh atau sebagian perusahaan untuk waktu paling lama 1 (satu) tahun; (d). pencabutan seluruh atau sebagian hak-hak tertentu atau penghapusan seluruh atau sebagian keuntungan tertentu, yang telah atau dapat diberikan oleh pemerintah kepada terpidana. 
makna hukuman berat terletak pada "terpidana harus menderita". Penderitaan yang dirasakan terpidana korupsi itu adalah wujud realitas kerugian yang ditimbulkan.

Sejalan dengan itu, Hyman Gross mengatakan: ${ }^{5}$ Punishment That fits crime is punishment in proportion to the culpability of the criminal conduct and it is what the preperator deserves for this crime.we now already how culpability it is to determined and it is easy enough then to decide on greater or lesser punhisment according to greater or lesser culpability among crimes, both for different kind of crimes, and for different instances of the same kind of the crime, but that is only the first step in keeping crime and punhisment in proportion. (Hukuman yang baik adalah hukuman yang sesuai dengan tanggung jawab dari perbuatan yang dilakukan. Kita sudah mengetahui bagaimana suatu tanggung jawab ditetapkan, dan ini cukup untuk menentukan apakah hukuman perlu diperberat atau diperingan. Namun hal ini barulah tahap pertama dalam menjaga agar kejahatan dan hukuman dapat sebanding). Memaknai apa yang dikatakan oleh Hyman Gross bahwa proporsionalitas suatu hukuman dengan perbuatan jahat adalah sebagai bentuk pertanggungjawaban pelaku, dimana ukurannya adalah kerugian yang ditimbulkan.

Berkaitan dengan hukuman dan kerugian, hal ini sejalan dengan azas di dalam $\mathrm{Hu}$ kum Pidana, yang mengatakan : Tiada Pidana tanpa kesalahan, dimana azas ini menekankan, bahwa bilmana seseorang memiliki kesalahan karena telah melakukan suatu perbuatan yang merugikan, maka harus ada hukuman sebagai pengimbalan atas perbuatannya. Oleh sebab itu harus jelas ukuran untuk menghukum seseorang. Hal ini sejalan dengan apa yang dikatakan oleh Cesare Beccaria: ${ }^{6}$ Bukan hanya $k a-$ rena kepentingan umum dari umat manusia bahwa kejahatan tidak boleh dilakukan, tapi bahwa kejahatan jenis apapun harus berkurang, sebanding dengan keburukan yang dihasilkannya untuk masyarakat. Oleh karena itu, perangkat yang dipergunakan oleh badan

\footnotetext{
5 Hyman Gross, A Theory of criminal Justice, New York : Oxford University Press, 1979, halaman 438.

6 Cesare Beccaria, Perihal Kejahatan dan Hukuman, Penerjemah Wahmuji, Jogjakarta : Genta Publishing, 2011, hal 17
}

pembuat undang-undang untuk mencegah kejahatan harus lebih kuat dalam proporsinya sebab kejahatan bersifat merusak keamanan dan kebahagian publik dan karena godaan untuk melakukannya semakin besar. Oleh karena itu, seharusnya ada proporsi yang tetap antara kejahatan dan hukuman. Berkaitan dengan itu juga, Eva Achjani Zulfa dan Indriyanto Seno Adji mengatakan, bahwa dasar untuk menghukum pelaku itu sangat bergantung kepada dua hal: ${ }^{\dagger}$ (a). nilai kerugian materiil yang ditimbulkan sebagai akibat dari tindak pidana yang terjadi; atau (b).pandangan atau penilaian masyarakat terhadap suatu perbuatan pada satu waktu tertentu.

Memahami hal itu, tidak dapat disangkal bahwa korupsi sebagai kejahatan telah menimbulkan kerugian, serta dipandang sebagai: $k e-$ busukan, keburukan, kebejatan, tidak bermoral, penyimpangan arti dari kesucian, dapat disuap. ${ }^{8}$ Dalam hal ini, korupsi telah mengurangi hak-hak sebagian besar warga Negara untuk memperoleh pelayanan pendidikan, kesehatan serta perumahan yang layak, transportasi yang murah dan fasilitas umum yang seharusnya dapat diberikan Negara. Sebagai suatu kejahatan yang luar biasa, Korupsi itu sendiri telah menimbulkan "amarah masyarakat". Dalam hal ini, wajar bila ada "amarah" masyarakat, karena sebagai pembayar pajak, warga negara tidak dihargai ketaatan serta kesetiannya mentaati hukum yang diwajibkan, terlebih partisipasi dalam pembangunan. Di satu sisi, Negara selalu menekankan agar setiap warga $\mathrm{Ne}$ gara patuh dalam membayar pajak, di sisi lain, pajak yang dibayar dinikmati hasilnya oleh sebagian kecil warga masyarakat melalui korupsi. Oleh sebab itu, keresahan masyarakat akibat korupsi itu cukup beralasan, sehingga pelaku korupsi itu sangat layak dijatuhi hukuman seberat-beratnya.

Berkaitan dengan itu, Hukuman seberatberatnya ditambah dengan pengembalian kerugian uang Negara sebagai uang pengganti, adalah sebanding dengan perbuatan yang dilakukan. Dalam hal ini, kesenangan serta kenikmatan yang dirasakan pelaku harus dibayar de-

7 Eva Achjani Zulfa dan Indriyanto Seno Adji, Pergeseran Paradigma Pemidanaan, Bandung : Lubuk Agung, 2011, hal. 39.

8 O.C. Kaligis, Antologi Tulisan Ilmu Hukum, Bandung : Alumni, 2011, hal. 190. 
ngan rasa sakit berupa penderitaan serta diasingkan dari lingkungan keluarga maupun masyarakat. Diasingkan dari masyarakat serta kebebasannya dibatasi, bahkan sebagian hak-hak nya di cabut, semua itu bentuk rasa sakit yang harus dijalani serta menjadi pengimbalan atas perbuatan yang telah menimbulkan kerugian keuangan negara.

\section{Hukuman Berat Dan Penjeraan}

Beberapa Jenis Hukuman yang ada di UU RI No 31 tahun 1999 tentang Pemberantasan Tindak pidana korupsi, sepertinya menjadi sangat terbuka untuk dibicarakan, apalagi di dalamnya terdapat hukuman yang sangat memberatkan, seperti : Hukuman mati, Pidana Penjara. Hukuman mati tentu sangat banyak yang menyukai, tapi banyak pula yang menentang. Pro dan kontra terhadap pidana mati terhadap pelaku korupsi, hampir dipastikan akan menjadi polemik yang berkepanjangan, dimana dalam hal ini tentu dilihat pada urgensi nya. Perlunya hukuman berat dimaksud, dikarenakan : angka kejahatan korupsi sudah sangat tinggi, lemahnya pencegahan dan penanggulangannya serta kurang berfungsinya institusi penegak hukum. Padahal kita ketahui bersama bahwa: ${ }^{9}$ untuk menanggulangi masalah korupsi kelihatan nya satau-satunya cara untuk menghilangkannya dengan memberikan hukuman seberat-beratnya, banyak mengusulkan diberikan hukuman mati sedangkan masalah hukuman mati sudah diatur dalam pasal 2 Undang-undang RI No 31 tahun 1999 tentang Pemberantasan Tindak Pidana, hanya saja dalam pelaksanaannya Hakim pada umumnya hampir tidak ada menjatuhkan hukuman mati karena dikaitkan dengan alasan yang memberatkan maupun meringankan dan faktor meringankan nya jauh lebih dominan dilihat dari batas hukuman tertinggi, pendidikan, dan lainlain.

Sebagaimana kita ketahui bersama, bahwa Sepanjang pemberantasan korupsi di Negara Indonesia, sepertinya pidana mati enggan untuk diterapkan, begitu pula dengan pidana penjara selama waktu dua puluh tahun. Mengapa itu dapat terjadi, sungguh suatu pertanyaan yang sangat berat untuk dicari jawab

\footnotetext{
9 Monang Siahaan, Korupsi Penyakit Sosial yang Mematikan, Jakarta : PT Elex Media Komputindo, 2013, hal. 93.
}

nya. Padahal kita ketahui bahwa Tindak pidana korupsi adalah suatu perbuatan yang dilakukan oleh orang-orang tertentu yang memiliki status sosial-ekonomi yang cukup tinggi, serta memiliki jabatan atau orang yang terpandang di masyarakat. Begitupun Pada waktu korupsi itu dilakukan, bukan dengan menggunakan senjata api, bukan pula dengan kekerasan bahkan tidak ada orang yang luka atau mati. Tapi tindak pidana ini begitu menyeramkan, menakutkan bahkan membuat orang banyak menjadi susah dan miskin. Bila memang demikian, mengapa harus menjadi ragu atau "takut" untuk menjatuhkan hukuman terberat sekalipun.

Indonesia yang di era demokrasi sekarang ini, dimana pengawasan serta penegakan hukum cukup intensif ditambah kinerja Komisi Pemberantasan Korupsi yang tanpa pandang buluh melakukan operasi tangkap tangan, sepatutnya tidak lagi ragu menerapkan hukuman seberat apapun kepada pelaku korupsi, mengingat banyak pejabat dan penyelenggara Negara yang masih berani melakukan korupsi. Sepertinya "pidana penjara" tidak ditakuti" dan kalah menarik dari uang. Daya tarik uang diperhadapkan dengan "pidana penjara" untuk waktu tertentu serta "rasa malu" menjadi hal biasa.

Dalam pada itu, penyebab lain tidak ditakutinya pidana penjara untuk waktu tertentu, sangat mungkin dikarenakan banyak terpidana korupsi yang diuntungkan berupa "kemudahan-kemudahan" yang diperoleh selama menjalani pidana penjara di Lembaga pemasyarakatan. "Kemudahan-kemudahan" yang diperoleh terpidana, seperti : kamar tidur yang memiliki mesin pendingin ruangan, kamar mandi, dimungkinkannya membawa alat komunikasi, serta memiliki uang dalam jumlah tertentu, bukan lagi menjadi rahasia. Mengapa itu dapat terjadi, semua itu karena lemahnya mental petugas dalam menegakkan aturan atau adanya pandangan petugas terhadap terpidana korupsi yang melihat bahwa terpidana korupsi "bukan penjahat". Berkaitan masih lemahnya pengawasan terhadap terpidana korupsi, mungkin disebabkan masih bercampur baurnya dengan terpidana lain.

Bila memang demikian, perlu jenis hukuman yang sangat berat dan memang dirasakan terpidana sebagai sesuatu yang menderitakan. Sejalan dengan perlu dan mendesaknya 
hukuman yang berat dan menyakitkan bagi terpidana korupsi, maka Hakim sudah sepatutnya mempertimbangkan pengenaan Pidana mati. Dalam hal ini, penjatuhan pidana mati sangat dimungkinkan karena memang ada diancamkan di UU RI Nop 31 tahun 1999 pada pasal 2 ayat (2) : Dalam Hal tindak pidana korupsi sebagaimana dimaksud dalam ayat (1) dilakukan dalam keaadaan tertentu, pidana mati dapat dijatuhkan. Menjatuhkan putusan berupa Pidana mati bagi terpidana korupsi memiliki dasar hukum yang kuat. Berkaitan dengan hukuman mati, pertanyaan mendasar adalah: ${ }^{10}$ Apakah hukuman mati menghasilkan efek jera yang lebih tinggi daripada bentuk-bentuk hukuman berat yang lain, seperti hukuman hukuman penjara dalam waktu lama, kalau hukuman mati tidak menghasilkan efek jera yang lebih tinggi maka tentu saja telah terjadi pengurangan yang "sewenang-wenang" atas hak untuk hidup.

Sehubungan dengan hukuman mati ber efek jera atau tidak kalau di jatuhkan kepada pelaku korupsi di Indonesia, tentunya harus diterapkan terlebih dahulu. Sebab di dalam sejarah pelaksanaan hukuman mati untuk pelaku korupsi, Indonesia masih belum memiliki tradisi untuk itu. Disamping itu juga, apakah hakim berani atau tidak menjatuhkan hukuman mati bagi pelaku korupsi. Sehubungan dengan keberanian Hakim memutus perkara tindak pidana korupsi dengan hukuman mati, itu semua sangat bergantung kepada : etos-etos yang berkembang, baik itu etos ke ilmuan, etos kerja, disiplin. Oleh karenanya menurut pasal $32 \mathrm{UU}$ RI No 4 tahun 2004 tentang kekuasaan kehakiman : Hakim yang bertanggung jawab dalam proses peradilan (litigasi) memikul tugas yang berat dengan penuh tanggung jawab, berdedikasi, dan memiliki integritas moral yang tinggi. Berdidikasi dan bertanggung jawab berarti memahami apa yang menjadi kewajibannya, yaitu : melakukan kekuasaan kehakiman dan wajib menjaga kemandirian peradilan. ${ }^{11}$

Sejalan dengan itu, Bagir Manan menga-

\footnotetext{
10 Todung Mulya Lubis dan Alexander Lay, Penyusun, Kontroversi Hukuman Mati, Perbedaan Pendapat Hakim Konstitusi, Jakarta : Penerbit Buku Kompas, 2009, hal. 105

11 Chaerudin, et al, Tindak Pidana Korupsi, Strategi Pencegahan dan Penegakan Hukum, Jakarta : Refika Aditama, 2008, hal. 66.
}

takan : ada beberapa faktor yang mempengaruhi perilaku Hakim dalam mempertahankan integritas, yaitu : (i) kualitas sumber daya manusia Hakim; (ii) adanya tekanan eksternal (pemerintah, publik atau pihak yang berperkara), (iii) fasilitas kesejahteraan, dan (iv) sistem pengawasan atau kontrol yang lemah dan tidak efektif. ${ }^{12}$ Hakim dalam memutus suatu perkara dengan pidana berat bahkan pidana mati sekalipun, dijamin oleh undang-undang, dimana kebebasan Hakim itu tidak dapat di intervensi dalam keadaan dan oleh siapapun tetapi kebebasan itu secara substansial dibatasi oleh hukum dasar Negara dan keadilan itu sendiri. ${ }^{13}$

Memahami hal tersebut, Hakim yang memiliki kemandirian dan dijamin oleh konstitusi tidak perlu lagi ragu untuk memutus suatu pidana mati bagi terpidana korupsi bilamana hal itu diyakini. Hukuman mati bagi masyarakat dipahami sebagai pidana yang efisien karena tidak memerlukan ongkos apapun. Hanya saja, Pidana mati baru bisa dikatakan efisien jika jarak antara penjatuhan pidana terhadap pelaku dengan pelaksanaan pidana mati itu tidak terlalulu lama. ${ }^{14}$ Dengan demikian, Pidana Penjara, Pidana Mati, harus dipandang sebagai hukuman berat yang dibutuhkan untuk menjerakan pelaku serta mencegah orang lain untuk menjadi takut melakukan korupsi. Bilamana hal itu tidak dilaksanakan, maka besar kemungkinan pejabat serta penyelenggara negara akan terbiasa dan tidak takut, karena hukuman yang diterima adalah Pidana Penjara paling minimal.

\section{Urgensi Hukuman Berat}

Memberantas korupsi sekarang ini sama berat dan sulitnya dengan memberantas peredaran narkotika. Dikatakan demikian, tidak lain dikarenakan korupsi sudah sangat lama menggerogoti perilaku dan mental Pejabat dan Penyelenggara negara di Indonesia. Salah satu bentuk korupsi yang banyak dilakukan oleh Pejabat dan Penyelenggara negara adalah Penyuapan. Hal itu seringkali halus dan seringkali sulit bagi para penyelidik untuk mengin-

\footnotetext{
12 Ibid, hal. 67.

13 Luhut M.P.Pangaribuan, Lay Judges \& Hakim ad Hoc suatu studi teoritis mengenai Sistem Peradilan Pidana, Jakarta : Fakultas Hukum Pascasarjana UI dengan Penerbit Papas Sinar Sinanti, 2009, hal. 186.

14 Op cit, Mahrus Ali, hal. 250.
} 
dentifikasi, apalagi membuktikan tindak korupsi yang sedang terjadi. ${ }^{15}$ Penyuapan itu sendiri biasa nya dilakukan oleh orang tertentu ke pejabat atau penyelenggara negara untuk memuluskan atau mendapatkan proyek-proyek berskala kecil dan besar. Menerima suap itu sendiri sudah menjadi bagian dari kebiasaan hidup mewah dan sering terjadi setiap waktu.

Memiliki "rumah serta mobil mewah" dan kekayaan yang jauh melampaui diatas penghasilan berupa gaji sudah bukan sesuatu yang memalukan, sepertinya kesenangan untuk menikmati uang negara dengan melanggar hukum "wajib" dilaksanakan, tanpa memikirkan akibat hukum dikemudian hari. Kenyataan demikian selalu diperlihatkan oleh Pejabat negara kepada masyarakat, pada saat mereka ditangkap atau tertangkap tangan melakukan korupsi, yang ditayangkan secara langsung oleh media elektronik, sepertinya tidak memperlihatkan "rasa malu", begitupun anggota keluarga. $^{* * *)}$ yang mengunjungi ke rumah tahanan, tidak sedikitpun merasa canggung atau malu di wawancarai oleh awak media. Padahal, mereka adalah bagian dari pelaku yang mungkin saja ikut mendorong agar tidak takut melakukan korupsi. Bila melihat kenyataan demikian, maka korupsi sudah dianggap biasa dan tidak perlu merasa malu atau takut dengan celaan dan hukuman.

Melihat kenyataan, dimana rasa malu, tidak takut untuk melanggar hukum, serta harga diri dikorbankan demi mendapatkan uang yang bukan haknya, Merupakan sisi gelap dari kehidupan pejabat serta penyelenggara negara. Mengapa demikian, karena terlalu banyak uang negara yang harus dilindungi dan itu se-

\footnotetext{
15 Ian Mc Walters, SC, Memerangi Korupsi, Sebuah Peta Jalan Untuk Indonesia, Surabaya : JP Books, 2003, hal. 265.

***) Pemanfaatan keluarga untuk melakukan praktik korupsi diduga dilakukan sejumlah kepala daerah yang diduga memiliki rekening gendut, yang kini diusut Kejaksaan Agung dan Komisi Pemberantasan Korupsi. Pelibatan keluarga dalam transaksi berbau korupsi ini termasuk modus yang banyak ditemui. Umumnya transaksi (di rekening gendut) menggunakan rekening anak istri atau orang terdekat, sekretaris atau ajudan. (Harian Kompas, Kamis, 18 Desember 2014), sejumlah kepala daerah yang memiliki rekening gendut kerap menyamarkan transaksi melalui rekening milik anak istri, kerabat dan perusahaan pribadi (editorial Media Indonesia, Harian Media Indonesia, Sabtu, 20 Desember 2014).
}

harusnya menjadi tugas Pejabat serta Penyelenggara Negara. Untuk itu, Negara dan Pemerintah perlu mengefektifkan Pengawasan dan Penegakan hukum dengan menyiapkan infrastruktur Peradilan serta sumber daya manusia Penegak hukum yang memiliki mental dan idealisme memberantas korupsi dengan berani menjatuhkan hukuman seberat-beratnya.

Menghukum Pelaku korupsi, apa dan siapa pun dia harus di lihat sebagai sesuatu yang perlu dan mendesak, mengingat banyak uang negara yang akan raib, serta merajalelanya pelaku dan hilangnya kewibawaan negara. Perlunya menghukum pelaku kejahatan di masyarakat teratur dan memiliki norma-norma yang hidup, tidak lagi dilihat sebagai bentuk pembalasan semata, namun harus dilihat sebagai kebutuhan Negara dan Masyarakat. Negara butuh alat pemaksa agar aturan-aturan yang ada di dalam hukum itu ditaati. Menjaga kekayaan dan uang Negara untuk saat ini satu-satunya cara adalah melalui Peraturan Perundang-undangan yang didalamnya tersedia $\mathrm{Hu}$ kuman Berat. Dimana Hukuman adalah suatu kondisi yang mampu mempengaruhi seseorang agar tidak berbuat jahat, serta Hukuman dapat dirasakan sebagai derita bagi terpidana, bilamana mengakibatkan orang itu menjadi jera. Dengan demikian, hal mendasar yang harus dilihat dari Hukuman adalah : hukuman itu memiliki kekuatan untuk mencegah orang menjadi jera serta orang lain menjadi takut. Disamping itu, harus diingat bahwa menghukum pelaku korupsi membutuhkan biaya yang tidak sedikit, dimana negara harus menyediakan infrastruktur serta petugas lembaga pemasyarakatan, maupun sarana lainnya. Dengan demikian, maka pelaksanaan hukuman itu harus efektif, efisien dan memperoleh hasil maksimal.

Menghukum dengan cara mengasingkan seseorang di Lembaga Pemasyarakatan adalah bentuk pencabutan dan pembatasan kemerdekaan pada dasarnya adalah sesuatu yang menakutkan, sebagaimana dikatakan R. A. Koesnoen: ${ }^{16}$ Bahwa Pencabutan kemerdekaan seseorang akan dirasakan lebih berat dari pidana mati atau pidana badanpun, masyarakat akan lebih takut melihat adanya orang-orang

${ }^{16}$ R.A. Koesnoen, Susunan Pidana dalam Negara Sosialis Indonesia, Bandung : Sinar Bandung, 1966, hal. 25. 
yang dicabut kemerdekaannya untuk bertahuntahun lamanya dari pada melihat orang-orang yang digantung ditengah alun-alun yang hanya terjadi sekilas mata dan terlihat sayupsayup dari jauh. Pendapat R.A. Koesnoen ini sejalan dengan apa yang dikatakan Gary C. Walters dan Joan E. Grusec, bahwa Pidana Penjara dapat menimbulkan efek samping berupa: ${ }^{17}$ Punishment has been said to a subsequent increase in aggressive behavior (dapat menimbulkan efek samping, berupa peningkatan perilaku agresif); Punishment is supposed to lead to psychal or phsyicological avoidance (hukuman dapat menimbulkan hambatan psikis atau psikologis; Punishment maybe capable of producing severe and chronic disturbance (hukuman dapat menghasilkan gangguan emosional kronis).

Bila mengacu kepada pendapat R.A. Koesnoen dan Gary C. Walters dan Joan E. Grusec tersebut, apakah seperti itu yang hendak di inginkan masyarakat bagi pelaku korupsi, dimana rasa sakit, berupa : pembatasan kemerdekan, menderita secara fisik dan psikis, ditambah situasi Penjara yang begitu menekan. Kenyataan demikian sangat mungkin, karena masyarakat memahami bahwa yang disebut hukuman itu adalah penderitaan, serta pembalasan atas perbuatan yang telah merampas dan menikmati sebagian dari hak-hak masyarakat untuk memperoleh manfaat dari uang Negara.

Hukuman, bagaimanapun jenisnya, tetap tidak mengenakkan, apalagi harus dijalani di tempat dimana pelaku belum mengenalnya. Jauh dari keluarga, dibatasi tembok serta hidup diatur oleh orang lain, makanan terbatas, belum lagi ada"pungutan tidak resmi", tidak bebas berkomunikasi dengan masyarakat luar, adalah hukuman yang tidak bisa dipungkiri oleh siapapun. Namun Kenyataan yang terjadi, dimana hukuman itu sangat ditakuti serta harus dihindari orang, kadangkala tidak sebanding dengan rasa takut untuk berbuat korupsi. Mengapa itu dapat terjadi, salah satunya adalah terlalu ringannya hukuman yang dijatuhkan Hakim. Dalam hal ini, seperti ada keraguan Hakim yang memeriksa dan memutus perkara untuk mengadaptasi apa yang menjadi kehen-

${ }^{17}$ Gary C. Walters dan Joan E Grusec dalam Petrus Irwan Pandjaitan dan Samuel Kikilaitety, Pidana Penjara Mau Kemana, Jakarta: Indhill Co. 2007, hal. 80. dak masyarakat. Akibatnya justru Hakim Agunglah yang "menambah hukuman" bagi pelaku.

Keraguan Hakim menjatuhkan hukuman maksimal bagi pelaku korupsi, terkesan "kurang menghargai" dan melihat keberadaan masyarakat Indonesia yang masih miskin. Dalam hal ini, dampak korupsi bagi orang miskin itu, sepatutnya di rasakan oleh Hakim. Dimana Realitas masyarakat Indonesia sebagian besar adalah masyarakat bawah baik dari sosial, ekonomi dan politik yang mempunyai posisi lemah dihadapan hukum. ${ }^{18}$ Hakim harus menyadari bahwa kerugian akibat korupsi bukan semata-mata kerugian pada uang Negara, tapi juga ada kerugian di masyarakat. Hakim harus memahami bahwa Masyarakat sekalipun tidak pernah membayar pajak, dia tetap warga $\mathrm{Ne}$ gara yang harus dilindungi dan dilayani hakhak dasarnya, sebab konstitusi Indonesia pun menjamin bahwa fakir miskin diurus oleh $\mathrm{Ne}$ gara.

Berkaitan dengan itu, Hakim saat menjatuhkan hukuman maksimal bagi pelaku korupsi, harus meyakini bahwa Hukum itu berpihak kepada masyarakat. Hal ini sebagaimana dikatakan oleh Jhering: ${ }^{19}$ Kepentingan Masyarakatlah yang menjadi Inti Hukum. Sebagai satu-satunya Penegak Hukum yang memberi rasa keadilan, harus memiliki padangan juga, bahwa menghukum pelaku korupsi, tidak saja memuaskan rasa keadilan masyarakat, tapi melalui hukuman dapat menyelematkan uang $\mathrm{Ne}$ gara, serta menyadarkan pejabat serta penyelenggara Negara. Disamping itu, hukuman dapat memulihkan hubungan Negara dengan pejabat dan penyelenggara Negara serta masyarakat. Terlebih-lebih lagi tegaknya wibawa Negara di mata warga Negara.

\section{Kesimpulan}

1. UU RI No 31 tahun 1999 tentang Pemberantasan Korupsi dan disempurnakan dengan UU RI No 20 Tahun 2001, merumuskan bahwa Korupsi adalah suatu Perbuatan yang memperkaya diri sendiri, orang lain dan Merugikan keuangan Negara. Adanya kerugian pada uang Negara, menjadi alasan

18 Umar Sholehudin, Hukum dan Keadilan Masyarakat, Malang : Setara Press, 2011, hal. 49

19 Bernard L .Tanya, et al, Teori Hukum, Jogjakarta : Genta Publishing, 2010, hal. 110 
untuk memberi hukuman kepada pelaku, dengan demikian kerugian dan hukuman harus setimpal;

2. Korupsi Sebagai Perbuatan yang dilakukan oleh pejabat, penyelenggara, maupun setiap orang yang menerima upah dari Negara, maka kepada pelakunya diberi hukuman yang bertujuan untuk menjerakan dan mencegah orang lain agar tidak melakukan korupsi;

3. Sebagai suatu perbuatan, Korupsi adalah suatu kejahatan luar biasa, oleh sebab itu penanganannya harus luar biasa, begitupun perlakuan terhadap pelaku harus luar biasa, yaitu dengan menjatuhkan hukuman seberat-beratnya, dimana urgensinya adalah menyelamatkan dan menjaga uang Negara, serta melindungi masyarakat dari kemiskinan serta memulihkan hubungan Negara dengan Pejabat serta Penyelenggara Negara dan Masyarakat.

\section{Saran}

1. Didalam UU RI No 31 tahun 1999 tentang Pemberantasan Tindak Pidana Korupsi dan disempurnakan dengan UU RI No 20 Tahun 2001, secara tegas dirumuskan Jenisjenis Hukuman serta ditentukannya hukuman minimal dan maksimal yang disesuaikan dengan perbuatan dan kerugian yang ditimbulkan. Oleh sebab itu, Hakim dalam menjatuhkan hukuman kepada pelaku sudah sepatutnya menilai proporsionalitas hukuman dengan kerugian yang ditimbulkan pelaku. Dalam Menjatuhkan Hukuman, Hakim harus memilih hukuman maksimal bagi pelaku korupsi dengan tujuan bahwa hukuman itu untuk menjerakan pelaku serta mencegah orang lain melakukan korupsi serta menyelamatkan uang Negara.

2. Pemerintah serta Komisi Pemberantasan Korupsi dan Badan Pemeriksa Keuangan Negara, sepatutnya tidak lagi mengedepankan penanggulangan korupsi, tapi juga mencegah korupsi dengan cara melakukan kordinasi dan supervisi.

3. Pemerintah serta Komisi Pemberantasan Korupsi dan Badan Pemeriksa Keuangan sudah seharusnya membuat aturan yang jelas dan terperinci serta tidak menimbulkan keraguan mengenai penggunaan uang Negara kepada pejabat serta penyelenggara Negara. Pemerintah serta Komisi Pemberantasan Korupsi dan Badan Pemeriksa Keuangan Negara sudah sepatutnya membuat aturan yang jelas dan terperinci untuk menghindari multi tafsir bagi Kepolisian, Kejaksaan, Hakim dan Komisi Pemberantasan Korupsi, sehingga menghindari kesalahan dalam menetapkan seseorang menjadi tersangka pelaku.

\section{Daftar Pustaka}

Indriyanto Seno Adji, Korupsi Kebijakan Aparatur Negara dan Hukum Pidana, Jakarta: Diadit Media, 2006

Hyman Gross, A Theory of Criminal Justice, New York: Oxford University Press, 1979

Luhut M.P. Pangaribuan, Lay Judges \& Hakim Ad Hoc Suatu Studi Teoritis Mengenai Sistem Peradilan Pidana, Jakarta: Fakultas Hukum Pascasarjana UI, Penerbit Papasa Sinar Sinanti, 2009

Monang Siahaan, Korupsi Penyakit Sosial Yang Mematikan, Jakarta: PT. Elex Media Komputindo, 2013

O.C. Kaligis, Antologi Tulisan Ilmu Hukum, Bandung: Alumni, 2011

Petrus Irwan Pandjaitan dan Samuel Kikilaitety, Pidana Penjara Mau Kemana, Jakarta: Indhill Co, 2007

R. A. Koesnoen, Susunan Pidana Dalam Negara Sosialis Indonesia, Bandung: Sinar Bandung, 1966 
Theodorus M. Tuanakotta, Menghitung Kerugian Keuangan Negara Dalam Tindak Pidana Korupsi, Jakarta: Salemba Empat, 2009

Todung Mulya Lubis dan Alexander Lay, Penyusun, Kontroversi Hukuman Mati, Perbedaan Pendapat Hakim Konstitusi, Jakarta: Penerbit Buku Kompas, 2009

Umar Sholehudin, Hukum dan Keadilan Masyarakat, Malang: Setara Press, 2011

Yunus Husein, Negara Sang Pencuci Uang, Jakarta: Pustaka Juanda Tiga Lima, 2008

\section{Surat Kabar}

Harian Kompas, Kamis, 18 Desember 2014

Harian Media Indonesia, Sabtu, 20 Desember 2014 